\title{
Application of Athletic Learning Models Based on Multilateral Development to Increase Motor Ability in Primary School Students
}

\author{
Slamet Widodo ${ }^{1}$ \\ ${ }^{1}$ Universitas Negeri Semarang, Indonesia \\ ${ }^{1}$ Corresponding email: widodo@gmail.com
}

\begin{abstract}
The purpose of this research is to know: improvement of motor ability in primary school students through application of athletic learning model based on multilateral development. This research was conducted by experimental method with One Group research design, Subjects Pre-Test-Posttest Design. The subject of this study is the students of grade 1 Primary School Banyuanyar Banjarsari Surakarta, which amounted to 36 students. The variables studied include independent variable that is multilateral based athletic learning and dependent variable that is motor ability. Technique of collecting data with test and measurement that is with motor ability test. Data analysis technique is done by statistical analysis, using t test at 5\% significance level, to fulfill assumption of result of research done by requirement analysis test with normality and homogeneity test. This research resulted in the conclusion that, there was a significant increase of motor ability in primary school students through the application of athletic learning model based on multilateral development
\end{abstract}

Keywords: Motor Ability, Athletic Learning Model, Multilateral Development

\section{Introduction}

Emphasis purpose of physical education in primary schools, especially the lower classes (classes I, II and III) is the improvement of motor skills (motor abilities) through a learning model-oriented holistic development (based Multi lateralised). In primary school children should be given a learning model that aims to develop multilateral or multi skill ability.

Motor ability is the foundation in the formation of qualified motion skills. Students who have a good ability motor, will allow to grow into skilled human beings. People who have a motor ability, relatively faster in learning a particular skill of the people who have a low ability motorcycle.

The formation of motion and motor development in primary school children is the basis of child development for the next. Physical education models, especially athletics that are not true applied at the primary school level can adversely affect the development of children in the future. Physical learning at the kindergarten level up to the third grade of primary school, given multilateral training, because at this time is the fastest period of complex motor development i.e. training forms aimed at developing all components bio motoric (Sukarman: 2000). Movement material that is trained in early childhood is a wide range of motion or multi skill.
Facts that occur in the field that the learning of physical education in primary school oriented to the improvement of specific skills (specific) on certain sports and not oriented to multilateral development. Teachers at the primary school level have generally directed children to master special skills for achievement sports. Though primary school children should not be required to excel in sports. The main priority of physical education for primary school children is to provide a solid foundation by mastering a wide range of motions (multi skill).

Problems that occur in Primary School that implementation athletic learning is still oriented towards the sport of achievement. In general, the concept of physical education based on multilateral development has not been socialized and has not been implemented. Physical education teacher has often followed $\mathrm{p}$ e workouts, upgrading, training or similar activities relating to physical education, but at the forum followed, less socialized multilateral-based learning (multi skill).

Motor ability needs to be developed in Primary school because it is the basis for various motion skills. In order to be able to have a motor ability Good, students need guidance, experience and practice learning model athletics based multilateral development. Based on the description it is necessary to conduct research on, application 
of athletic learning model based on multilateral development to improve motor ability in primary school students.

\section{Athletics for Primary School Students}

Athletics is the oldest sport of any other sport. Athletic movements are present in everyday life. Movements such as roads, running, throwing and jumping are the movements people have made since ancient times, both to survive and to be used as a means of self-defense.

Athletics is one of the sports that is effective enough to improve the ability of the students or children's movement. Many of the benefits derived from these athletic activities, both physically and mentally. Athletic exercise contains the necessary motion elements in all sports, so it can be said that athletics is the mother of all sports. Athletics is one of the elements of Physical Education and Health is also a component of overall education that prioritizes physical activity as well as fostering healthy life and harmonious, balanced and balanced physical, mental, social and emotional development (Widya, 2004). Through athletic activities can establish physical and mental health.

The implementation of physical education, especially athletic education, leads to the achievement of the established competencies. Competency standards of physical education graduates, especially athletic athletics that is, practice basic motion run, jump and walk in simple game and basic values of sportsmanship such as honesty, cooperation and others.

A good learning program is a learning program in accordance with the conditions, the perpetrators (students). Giving good learning should consider the level of ability and development of students. Teachers, especially in Primary Schools need to know the growth and development characteristics of elementary students.

\section{Motor Ability}

Motor ability has the same meaning as basic motor skills or motor skills. Sukintaka (2004: 78) suggests that, "Motor ability is the quality of individual motion in motion, both non-sport movement and motion in sports or maturity of motor skills appearance". Rusli Lutan (1988: 96) states that, "Motor ability is more accurately referred to as the capacity of a person associated with the execution and demonstration of a relatively inherent skill after childhood." Motor ability is the presence of innate abilities and abilities gained in performing motion skills of a general or fundamental nature, beyond the ability of highlevel specialist sports.

The ability of motion (motor ability) is a characteristic of inherited and relatively sedentary individuals, which underlie and support the formation of skills (Schmidt, 1991 : 311). Motor ability is the underlying capability of motion, outside of special techniques in sports. Motor ability is a very important element for skill formation. That's why the motor ability of students is developed through physical education.

\section{The Concept of Multilateral Development}

Multilateral development is a movementbased development of flexibility in children as a broad -based effort (broad base) on performance coaching in the future. Multilateral development (multi skill) is the development of various skills and motor abilities (motor abilities) and adaptation to various needs of the training load to develop the overall adaptation (Bompa, 2009:30)

Teachers must be creative to create a model of physical education education with multilateral development based. An appropriate multilateral development-based learning model that can be implemented in physical education and sports education in schools. Designing multilateral development and implementation in physical education in schools that can play a role in sports performance enhancement

Physical Education has a big role in multi skill or multilateral development. Benefits of a physical education-based learning model multilaterally, among others: (1) Establish comprehensive fitness: physical, spiritual and social. (2) Placing the child as a child, not as a small adult, (3) It is the foundation of future sports chains, (4) as a means of finding a child's talent.

\section{Multilateral-Based Athletic Learning Model}

Physical education learning based on multilateral development is a learning that is designed by loading various motions such as walking / running, jumping, throwing, catching, rolling, kicking and so on. According to Tangkudung, J. (2006: 9) that, multilateral 
or multi skill also developed by Eastern European countries, where schools perform basic training programs that develop basic skills such as, running, jumping, throwing, catching, rolling and maintaining balance ".

Multilateral-based learning has not included the development of specific motion skills in sports. The main goal of learning is the overall development of the various physical components of the child. Complete physical development is an important foundation for the development and growth of children in the future.

Learning models developed can be games and competitions or competitions. Teachers should be able to pack with interesting forms of activity. Approach to play/games and competition, to be one approach in learning that can be developed in athletic learning (Saputra YM, 2001: 5).

Multilateral development (multi skill) is the development of various skills and motor abilities (motor abilities) and adaptation to various needs of the training load to develop the overall adaptation (Bompa, 1999: 30). Multilateral development is a counter specialization from an early age. Early specialization aims to direct children to certain sports to be able to reach sports achievements immediately. Multilateral development provides comprehensive baseline (broad base) on the development achievements in the future.

Physical Education has a big role in multi skill or multilateral development. Benefits of a physical education-based learning model multilaterally, among others: (1) Establish comprehensive fitness: physical, spiritual and social. (2) Placing the child as a child, not as a small adult, (3) It is the foundation of future sports chains, (4) as a means of finding a child's talent.

Multilateral based athletic learning, developing basic motion abilities (motor ability). Multilateral-based athletic learning provides a solid foundation for the development of various aspects of child movement, including, running, jumping, crawling, throwing, and so on. Multilateral development is a movement-based development of flexibility in children as a broad -based effort (broad base) on performance coaching in the future. Complete physical development is an important foundation for the development and growth of children in the future. With the multilateral development of children it is expected that children have a strong foundation for the next development. The strong foundation is expected in the future to support the achievement maximally.

\section{Method}

The method used in this research is experimental method using One Group research design, Subjects Pre-test-Posttest Design. The population of this study is the students of grade 1 Primary School at Banyuanyar Banjarsari Surakarta, which amounted to 36 students. In this study all members of the student population of grade 1 Primary School at Banyuanyar Banjarsari Surakarta, which amounted to 36 students into a sample of research. The variables studied include independent variable that is multilateral based athletic learning and dependent variable that is motor ability. Technique of collecting data with test and measurement that is with motor ability test. Data analysis technique is done by statistical analysis, using t test at 5\% significance level, to fulfill assumption of result of research done by requirement analysis test with normality and homogeneity test.

\section{Result and Discusion}

Description of result of data analysis result of motor ability test done at first test and posttest presented in table form as follows:

Table 1. Description Score Data Test Results Motor Ability

\begin{tabular}{lcccc}
\hline \multicolumn{1}{c}{ Test Item } & Pre-Test & Post-Test & Enhancement Enhancement (80) \\
\hline Standing Broad Janip & 45.55 & 54.45 & 890 & $19.53 \%$ \\
\hline Softball Throw & 48.53 & 51.47 & 293 & $6.05 \%$ \\
\hline Basket Ball Put & 46.10 & 53.90 & 7.80 & $16.93 \%$ \\
\hline Rum 30M & 45.71 & 54.29 & 8.58 & $18.78 \%$ \\
\hline Total Score & 185.89 & 214.11 & 28.22 & $15.18 \%$ \\
\hline
\end{tabular}

In this study subjects were treated with multilateral based athletic learning. After being treated, then performed a motor ability test. From result of motor ability test at first test and posttest then do difference test, which result are: 
Table 2. Summary of Test Results Difference Values Improved Motor ability Between PreTest and Post-Test.

\begin{tabular}{cccccc}
\hline $\begin{array}{c}\text { Grou } \\
\mathrm{p}\end{array}$ & $\mathrm{N}$ & $\mathrm{M}$ & $\mathrm{M}_{\mathrm{d}}$ & $\mathrm{t}_{\text {count }}$ & $\begin{array}{c}\mathrm{t}_{\text {table }} \\
5 \%\end{array}$ \\
\hline $\mathrm{K}_{1}$ & 3 & 185.86 & & & \\
& 5 & 1 & 28.25 & 19.97 & 2,04 \\
$\mathrm{~K}_{2}$ & 3 & 214.11 & 0 & 3 & 2 \\
& 5 & 1 & & & \\
\hline
\end{tabular}

With $\mathrm{db}=\mathrm{n}-1=35$ and a significance level of $5 \%$, the limit value of the null hypothesis rejection in table $t$ is 2,042. From the $t$ test that can be obtained $t$ value of 19.973, which turns out the value is greater than the value of t table $5 \%$ is 2042 . Thus the null hypothesis is rejected, meaning that there is a significant difference between the increased motor ability value at the pretest and the posttest.

Calculation of percentage of increase is useful to know how much the increase motor ability. The percentage of motor ability improvement in the pretest and the posttest are as follows:

Table 3. Summary Calculation of Percentage Values of Motor Enhancement Ability Pretest and Posttest

\begin{tabular}{cccc}
\hline Test & $\mathrm{N}$ & $\begin{array}{c}\text { Increased } \\
\text { Rate }\end{array}$ & $\begin{array}{c}\text { Increase } \\
\text { Percentage }\end{array}$ \\
\cline { 1 - 3 } Pretest & 36 & 185.861 & \multirow{2}{*}{$15.18 \%$} \\
\hline Posttest & 36 & 214.111 & \\
\hline
\end{tabular}

From the above results can be seen that the percentage increase in early tests and motor end test ability of $15.18 \%$. Thus it can be concluded that there is a significant increase of motor ability from the pretest to the posttest.

From the results of data analysis can be seen that there is a significant difference between motor skills test results in the pretest and the posttest. Based on the calculation of the percentage of motor ability improvement from the pretest to the posttest can be seen that students have an average motor ability increase of $15.18 \%$. Thus it can be concluded that motor ability students have a significant improvement after getting the treatment of multilateral based athletic learning.

The main purpose of learning based multilaterals is a thorough development of the various physical components of the child.
During learning the students get the material and are given the greatest opportunity to perform various movements, running, jumping, jumping, throwing and crawling. Learning models that are conducted include imitations, games, competitions and matches. Playing/games and competition is a very interesting learning approach for children. Competition and games can make students more active and move as much as possible. Through multilateral development-based athletic learning various physical components are thoroughly improved so that motor ability of students can also increase.

\section{Conclusions}

Based on the results of research and data analysis results that have been done, can be obtained the following conclusion: There was an increase of motor abilities significantly in primary school students through the application of learning models based athletic multilateral development

Multilateral-based learning can develop a thorough physical component which is an essential foundation for future child development and growth. Learning-based multilateral athletics is very suitable for children, especially in primary school, for primary school students are a group of children who require good physical grounding for the growth of and the future development.

\section{References}

Bompa, TO 2009. Periodization Theory and Methodology of Training. Kendall / Hant: Human Kinetics..

IAAF. 2004. Kids' Athletics, A Team Event for Children. RDC IAAF.

Rusli Lutan. 1988. Learning Motor Skills, Introduction Theory and Method.

Jakarta : Department Education and Culture Directorate General of Higher Education Development Project Educational Institution of Education Personnel.

Saputra, YM 2001. Basics of Athletic Skills. Jakarta: Ministry of National Education, Directorate General of Primary and Secondary Education Working with the Directorate General of Sport

Schmidt, RA., 1991. Motor Learning and Performance: From Principle to 
Practice. New York : Human Kinetics Ltd

Sukarman. 2000. Sports and Physical Education Is a Forum for the Formation of Whole Indonesian Man. Paper. Presented at the PG Sports Scientific Seminar XV Year 2000. Malang: Committee of Scientific Seminar of XV National Sports Week of 2000

Sukintaka. 2004. Theory of Physical Education, Philosophy of Learning and the Future. Bandung: Yayasan Nuansa Cendekia Foundation.

Tangkudung, J. 2006. Sports Coaching, Coaching Sports Achievement. Jakarta: Publisher Cerdas Jaya.

Widya, AMD 2004. Learn to Practice Basic Athletic Motions In Playing. Jakarta: PT. Raja Grafindo Persada. 